Universidad de Lima

Facultad de Derecho

Carrera de Derecho

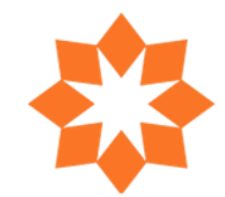

UNIVERSIDAD

DE LIMA

\title{
CIVIL: "RESPONSABILIDAD CIVIL" Y ADMINISTRATIVO: "COMPETENCIA DESLEAL"
}

Trabajo de Suficiencia Profesional para optar el Título Profesional de Abogado

\section{JAVIER ALEJANDRO NIETO VEGA \\ Código 20051955}

Lima - Perú

Octubre 2019 


\title{
CIVIL: "RESPONSABILIDAD CIVIL"
}

\section{Resumen:}

El presente expediente trata acerca de una demanda de indemnización por daños y perjuicios presentada por el interesado con el Gobierno Regional de La Libertad, a raíz de un despido injustificado.

Materia: Derecho Civil/ Responsabilidad Civil

Demandante: Armando Antonio Torres Odiaga

Demandado: Gobierno Regional de la Libertad

Nro. de Expediente: DE-RESPCIV0089/02205-2007-0-1601-JR-CI-03

\section{ADMINISTRATIVO: "COMPETENCIA DESLEAL"}

\section{Resumen:}

Un diario denuncia a otro medio por la presunta comisión de actos de competencia desleal en las modalidades de engaño y denigración con motivo de una publicación.

\author{
Materia: Derecho Administrativo/ Competencia Desleal \\ Denunciante: Diario El Tiempo SAC. \\ Denunciado: Diario Prensa Popular SAC \\ Nro. de Expediente: DE-INDEC0483/270-2012/CC
}

